\title{
THE GENERA OXYSTEGUS AND PSEUDOSYMBLEPHARIS (POTTIACEAE, BRYOPHYTA) IN THE CAUCASUS
}

\author{
РОДЫ OXYSTEGUS И PSEUDOSYMBLEPHARIS \\ (POTTIACEAE, BRYOPHYTA) HA KABKA3E
}

\author{
ELENA A. IGNATOVA ${ }^{1}$, OXANA I. KUZNETSOVA ${ }^{2}$, MiCHAEL S. IGNATOV ${ }^{2} \&$ HERIBERT KÖCKINGER $^{3}$ \\ ЕЛЕНА А. ИГНАТОВА ${ }^{1}$, ОКСАНА И. КУЗНЕЦОВА ${ }^{2}$, МИХАИЛ С. ИГНАТОВ ${ }^{2}$, ХЕРИБЕРТ КЁКИНГЕР $^{3}$
}

Abstract

\begin{abstract}
In the course of recent floristic studies in the Caucasus, Oxystegus daldinianus (De Not.) Köckinger, O. Werner \& Ros was collected in the Black Sea coastal area, and two specimens from Dagestan were identified as Pseudosymblepharis bombayensis (Müll. Hal.) P. Sollman. Both species are newly recorded for Russia. Two localities of $O$. daldinianus and one of $P$. bombayensis were revealed in Georgia based on re-identified herbarium collections. Distinctiveness of these species based both on morphological characters and nuclear ITS sequences is discussed.
\end{abstract}

Резюме

Два новых для России вида были недавно собраны на российском Кавказе: Oxystegus daldinianus (De Not.) Köckinger, O. Werner \& Ros найден на Черноморском побережье в окрестностях Лазаревского; Pseudosymblepharis bombayensis (Müll. Hal.) P. Sollman выявлен в коллекциях из Дагестана. В результате ревизии гербарных коллекций оба вида были также найдены в Грузии. Обсуждаются морфологические отличия этих видов от Oxystegus tenuirostris (Hook. \& Taylor) A.J.E. Sm., а также данные анализа последовательностей ITS. Уточнено распространение $O$. tenuirostris на российском Кавказе.

KEYWORDS: Caucasus, ITS, mosses, Oxystegus, Pottiaceae, Pseudosymblepharis, Russia

\section{INTRODUCTION}

The history of the genus Oxystegus (Limpr.) Hilp. was recently overviewed by Köckinger et al. (2010). It was treated as a subgenus of Trichostomum Bruch by Zander (1993), and many recent floras followed this point of view (Smith, 2004; Guerra et al., 2006; Hallingbäck et al., 2008, etc.), while generic rank of Oxystegus was accepted in most Russian floras and check-lists (Savicz-Lyubitskaya \& Smirnova, 1970; Ignatov \& Ignatova, 2003; Ignatov, Afonina, Ignatova et al., 2006). A molecular phylogenetic studies of Trichostomoideae has been provided by Werner et al. (2005) who showed that generitypes of Trichostomum and Oxystegus are not closely related. At the same time, Köckinger et al. (2010) stated that the circumscription of Oxystegus remains unclear and its separation from Pseudosymblepharis Broth. is problematic.

Köckinger et al. (2010) revised the genus Oxystegus in Europe, considering also nrITS sequence data. Five species and one subspecies were recognized, including one species, O. minor Köckinger, O. Werner \& Ros new for science. The taxonomic status of $O$. daldinianus, which was previously treated as a variety of Trichostomum tenuirostre, was raised to species rank.
Until recently, only one species of the genus Oxystegus, O. tenuirostris, was known in Russia. In the Russian Caucasus it was reported from the Black Sea coastal area as well as from the forest belt in the mountains of Kabardino-Balkaria, Karachaevo-Cherkessia, etc. (Ignatov et al., 2002; Ignatova et al., 2005, 2007; Kharzinov et al., 2004).

During an excursion in Sochi area at Black Sea coast in 2012 we collected a peculiar specimen, which was tentatively identified as $O$. daldinianus. However, as some characters of this specimen did not fit in the species description, we checked its identity with nrITS.

Along with some other Oxystegus samples, we included in molecular analysis two other puzzling collections made in Dagestan. Resembling in some respects $O$. tenuirostris, the specimens look somewhat different in having longer and narrower leaves and stronger costa.

\section{MATHERIALS AND METHODS}

Twelve collections from Russia were used in the molecular analysis, including one specimen of $O$. daldinianus, 9 of $O$. tenuirostris, and 2 ' $O$. sp.' from Dagestan; 44 accessions were taken from GenBank for comparison, including Tortella, Trichostomum, Pseudosymblepharis, Oxystegus, and Pleurochaete species. Specimen data are

\footnotetext{
1 _ Biological Faculty, Moscow State University, Moscow 119234 Russia - Россия 119234 Москва, Московский государственный университет, Биологический факультет; e-mail: arctoa@list.ru

2 - Main Botanical Garden of Russ. Acad. Sci., Botanicheskaya 4, Moscow 127276 Russia - Россия 127276 Москва, Ботаническая 4, Главный ботанический сад РАH; e-mails: oikuznets@gmail.com \& misha ignatov@list.ru

3 - Roseggergasse 12, A-8741 Weisskirchen, Austria; e-mail: heribert.koeckinger $\bar{a}$ aon.at
} 


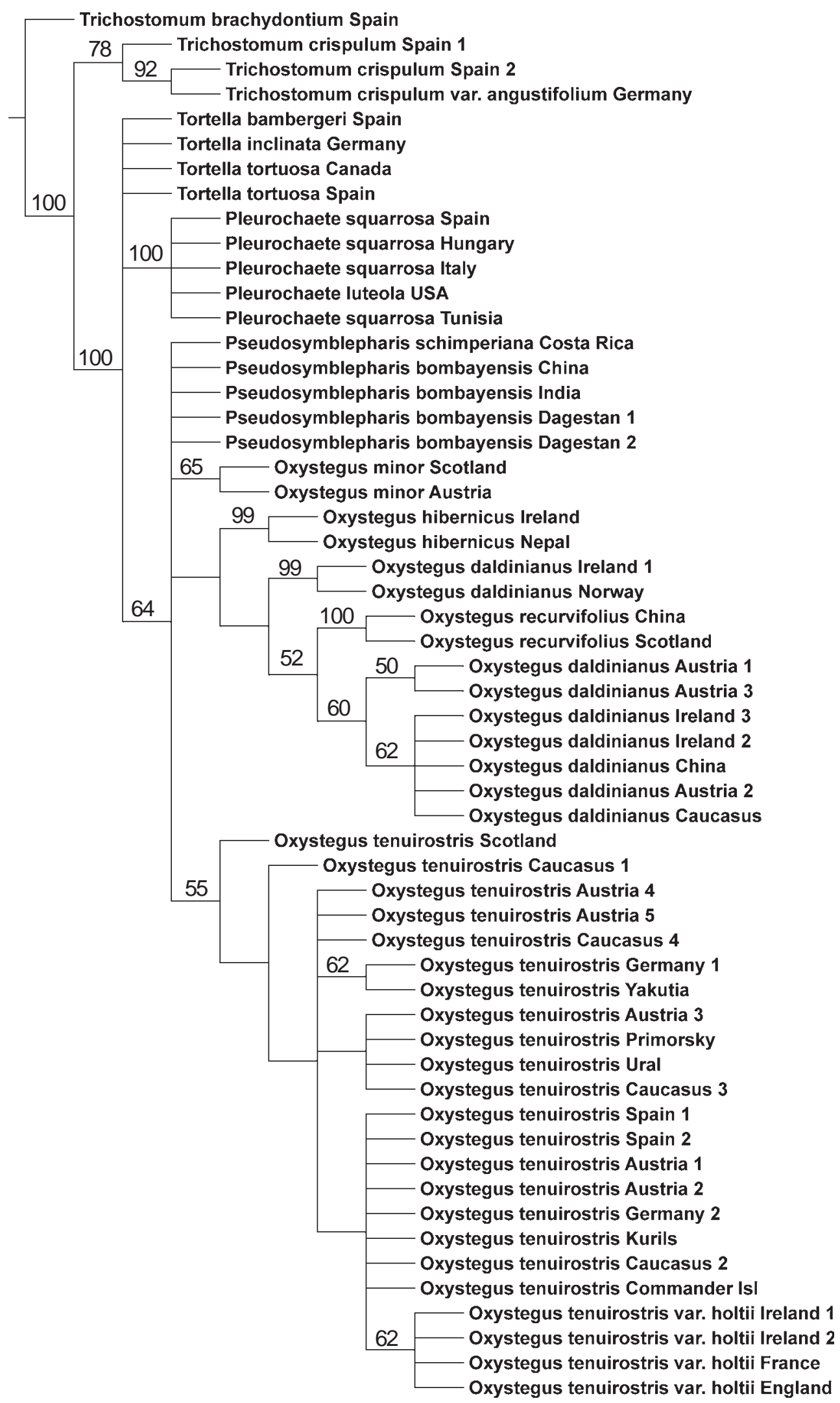

Fig. 1. Strict consensus tree of 1786 shortest trees $(L=228)$ found in ratchet parimony analysis of ITS sequences $(L=246$; $\mathrm{RI}=0.89 ; \mathrm{CI}=0.75$ ). Jackknife support $>50$ calculated by 1000 iterations is shown above branches. 
given in Appendix 1. Six specimens of Pseudosymblepharis, which were kindly send to us by Drs. Ph. Sollman and D.G. Long, were used for morphological comparison, and collections of $O$. tenuirostris from LE, MHA and MW were revised. The tree was rooted on Trichostomum brachydontium.

Nuclear ITS1-5.8S RNA-ITS2 region was studied. The protocol of DNA extraction and amplification was the same as in Gardiner et al. (2005). Sequences were aligned manually in Bioedit (Hall, 1999) and analysed with maximum parsimony method in NONA (Goloboff, 1994) under the Winclada shell (Nixon, 1999). The strict consensus tree was obtained in ratchet parsimony analysis (200 iterations, hold 25, characters to sample 100), that found 1786 shortest trees $(\mathrm{L}=228)$. Jackknife support was calculated for 1000 iterations (number of searches 10, hold 10, do $\max )$.

\section{RESULTS}

As the present analysis was done using previously obtained GenBank data already analyzed by Köckinger et al. (2010), the overall tree topology is not discussed here in all details. The analysis has been addressed mostly to finding the identity of unclear Caucasian species.

The strict consensus tree (Fig. 1) resolved species other than from the genus Trichostomum in polytomy formed by Tortella species and two clades: 1) clade of Pleurochaete species, and 2) Pseudosymblepharis + Oxystegus clade.

Within the Pseudosymblepharis + Oxystegus clade, species of the former genus form a polytomy, which includes specimens from the Caucasus, India, China and Costa Rica. Species of Oxystegus formed three clades, two with single species, O. tenuirostris and $O$. minor, and third one with three other species included in the analysis.

A topology of the Pseudosymblepharis + Oxystegus clade is similar to that obtained by Köckinger et al. (2010). Specimen of Oxystegus daldinianus from the Caucasus is resolved within the larger one of two subclades formed by specimens of this species. All specimens of $O$. tenuirostris from Russia are grouped with GenBank accessions of this species.

\section{DISCUSSION}

ITS analysis confirms the placement of the specimen from the Black Sea coastal area in Oxystegus daldinianus, in spite of certain difference in leaf shape. Köckinger et al. (2010) found this species in two separate clades in their molecular phylogenetic tree. The specimen from the Caucasus is grouped with specimens used in that study from Ireland, Austria, and China.

Two specimens from Dagestan which were identified as Oxystegus tenuirostris with question mark, were found outside the clade formed by that species, but in a polytomy formed by Pseudosymblepharis species.

The latter genus is unknown in Europe and distributed in tropical and warm-temperate areas of the world (Zander, 1993). A taxonomic revision of Pseudosymble- pharis in Asia was published by Sollman (2000), who recognized in this region only one species, $P$. bombayensis, and reduced 23 names to its synonymy. He discussed its diagnostic characters and variation, as well as provided a detailed comparison with Oxystegus tenuirostris [as Trichostomum tenuirostre], because poorly developed specimens of $P$. bombayensis could be confused with the latter species. In some features discussed by Sollman (1.c., p. 142) specimens from Dagestan agree with O. tenuirostris: (1) leaf base hardly expanded, without shoulders above it vs. leaf base widened, with shoulders in P. bombayensis; (2) cells in transitional zone from base to lamina not porose vs. transitional cells usually porose. However, according to Sollman (1.c.), these characters can be variously expressed in P. bombayensis. At the same time, the Dagestan specimens are more similar to $P$. bombayense habitually, in spite of smaller size of plants (shorter stems): in dry state their leaves are strongly crisped to circinate, mainly due to stronger costa. Costa width at leaf base is ca. $90 \mu \mathrm{m}$ in the Dagestan specimens, much wider than it is common for O. tenuirostris; it occupies ca. $1 / 4$ or even $1 / 3$ of limb width, which is not a case of the latter species. More or less straight leaf margins and dense papillae, obscuring the lumen in surface view, also place the Dagestan specimens together with Pseudosymblepharis.

There are some other characters which pull Dagestan specimens together with $P$. bombayensis: (1) in stem transverse section outer cortical cells are thick-walled and brownish, central strand is weak vs. well-differentiated hyalodermis and central strand are usually present in $O$. tenuirostris; (2) dorsal side of costa is formed by elongate cells and smooth throughout vs. distal surface cells on dorsal side of costa, near leaf apex, are usually subquadrate and papillose in $O$. tenuirostris (see Köckinger et al., 2010); (3) marginal cells of leaf base are thin-walled in several rows, contrasting with thick-walled inner cells, and colorless marginal cells extend upwards and forming a border (like in Tortella, but less clearly delimited) vs. marginal and inner basal cells equally thin-walled, not extending upwards at margins and not forming a border in $O$. tenuirostris. Pseudosymblepharis bombayensis is very variable in morphological characters (Sollman, 2000), and first molecular data, based on a rather restricted sampling, also show a considerable variability of its ITS region (Köckinger et al., 2010). Specimens from Dagestan are most similar in ITS to the specimen from India (GenBank accession HM049777). We were able to study a duplicate of this sample (D.G.Long \#26379); it represents a comparatively slender plant with variously expanded leaf bases, some of them only weakly widened and similar to leaves of Dagestan plants. According to the results of molecular analysis and a comparison of morphological characters, and taking into account a contemporary wide taxonomic concept of $P$. bombayensis, we refer specimens from Dagestan to the latter species. 


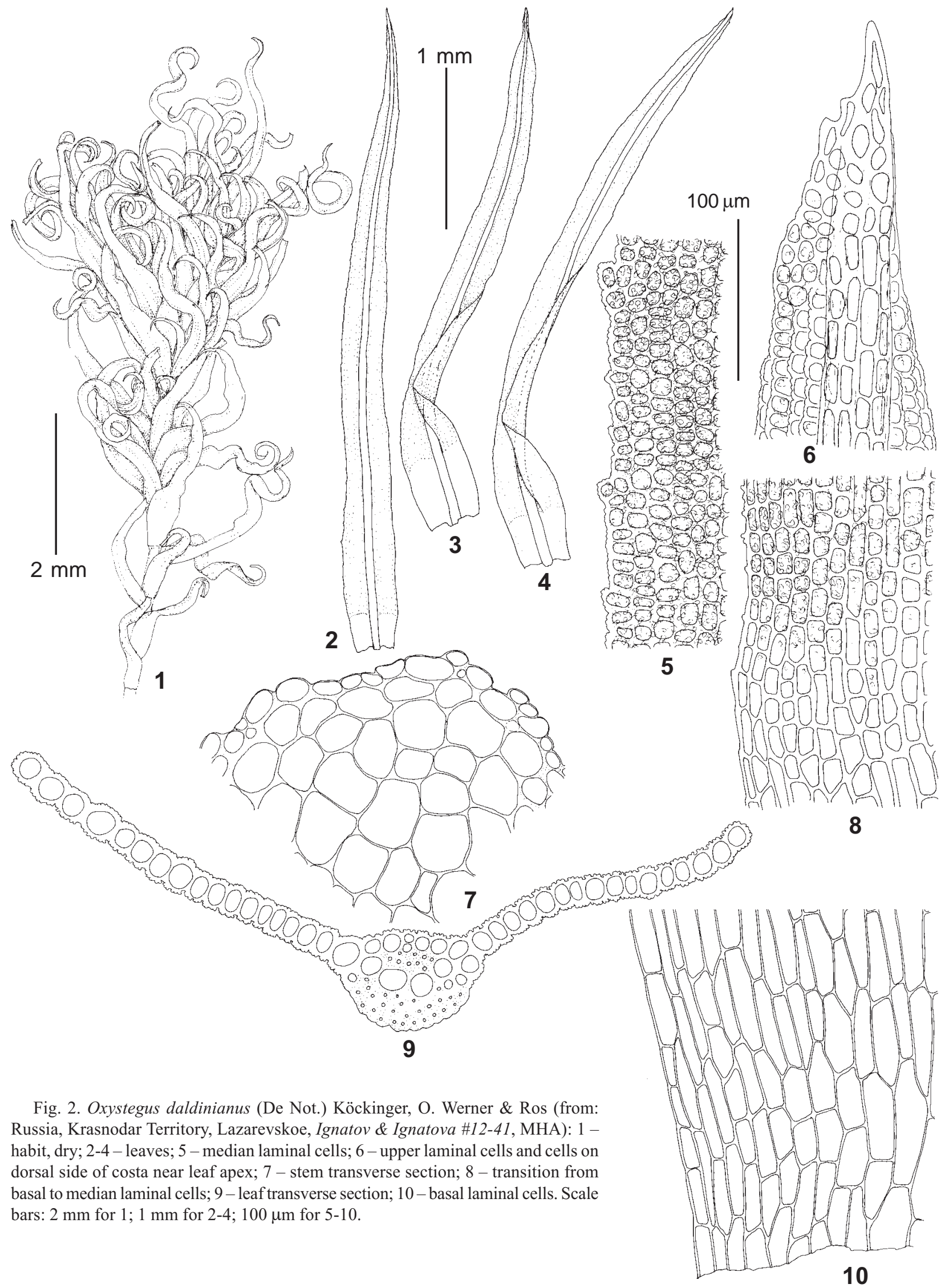




\section{TAXONOMY}

Oxystegus daldinianus (De Not.) Köckinger, O. Werner \& Ros, Nova Hedwigia Beih. 138: 39. 2010. - Didymodon cylindricus var. daldinianus De Not., Atti Reale Univ. Genova 1: 563. 1869. - Trichostomum tenuirostre var. daldinianum (De Not.) Dixon, Laubm. Deutschl. 1: 571. 1888.

Fig. 2.

Plants rather large for the genus, to $3(-5) \mathrm{cm}$ high, in loose tufts, yellowish green or pure green above, brownish below. Stems simple or sparsely branched, evenly foliated, rounded in transverse section, hyalodermis present, sclerodermis in (1-)2-3 rows, medullar cells with moderately thickened walls, central strand absent. Leaves crisped when dry, patent to spreading when moist, not or weakly fragile, 4-6 $\mathrm{mm}$ long, 0.5-0.6 mm wide at base, linear-lanceolate, limb slighly concave, gradually narrowing to the apex or parallel-margined in middle part of leaf and quickly tapered to cuspidate in apical part, sheath shorter than wide or equal in width and length, of the same width as limb or slightly wider or narrower; costa strong, 80-100 $\mu \mathrm{m}$ wide at base, gradually narrowing from base to apex, percurrent to shortly excurrent, strongly prominent abaxially, in transverse section semicircular to nearly circular, with one row of guide cells, large dorsal and small ventral stereid band, adaxial epidermis differentiated, surface cells on adaxial side of costa subquadrate and papillose, surface cells on abaxial side of costa elongate rectangular, thick-walled, smooth throughout; margins plane, remotely and bluntly toothed, not or weakly undulate in proximal part of limb; distal and median laminal cells subquadrate, $8-12(-15) \mu \mathrm{m}$, with moderately thickened walls, papillae small to moderately sized, bifid, not very dense, not obscuring lumina; basal laminal cells rectangular, 30-55 $\times 12-14 \mu \mathrm{m}$, hyaline, smooth, thin-walled, transition to papillose median cells gradual, cells of transitional zone thick-walled, not porose. Dioicous. Sporophytes not seen in specimens from the Caucasus.

Differentiation. Oxystegus daldinianus differs from O. tenuirostris in usually larger size of plants, less fragile leaves and weakly, bluntly and remotely denticulate margins of the limb, while the latter species is characterized by small plants, often strongly fragile leaves with variously notched margins (rarely toothed and then sharply). Elongate and smooth cells on adaxial side of costa, including its distal part, are very helpful for separating of $O$. daldinianus from $O$. tenuirostris, which has short rectangular to subquadrate and usually papillose surface cells on abaxial side of costa in distal uppermost part of leaf. Stems of $O$. daldinianus always lack central strand, while in $O$. tenuirostris it is usually present. Köckinger et al. (2010) list some other characters in which these species differ: (1) ligulate leaves with parallel margins in mid-leaf and suddenly narrowed apical part in $O$. daldinianus vs. linear-lanceolate leaves gradually narrowing to the apex from mid-leaf or below in O. tenuirostris; (2) sheath often narrower than limb vs. sheath often slightly wider than limb, respectively. However, these characters are not clearly seen in specimens from the Caucasus. The narrow leaves of these plants may be due to the warm climate. In most parts of the known distribution area of the species the climate is distinctly colder.

Ecology. Oxystegus daldinianus has been found in places not far to the Black Sea coast where calcareous sedimentary bedrocks are represented. In Sochi area it was collected from crevices of rock outcrop near the road, in rather open place. In Adzharia, according to label information, it grew on rocks in beech forest on mountain slope, on rocks shaded by ferns, along a stream, and on rotten $\log$. According to Köckinger et al. (2010), there is no considerable difference in rock preference between $O$. daldinianus and O. tenuirostris: the former species grows on rocks with acidic to subneutral reaction, and the latter one prefers subneutral sites, but also tolerates moderately acid to nearly neutral rocks and is rarely found even on limestones. Interestingly, a revision of herbarium material from the Caucasus revealed that all specimens from the Black Sea coastal area identified as $O$. tenuirostris belong to other taxa, and the latter species is apparently absent from this area with calcareous bedrocks, probably because of the already too warm climate. At the same time, O. daldinianus turned to be the only species of the genus in this generally calcareous area; however, it is not widespread there and never grows directly on limestone rock.

Distribution. In the Caucasus, O. daldinianus is restricted to the Black Sea coastal area. At the moment it is known from Lazarevskoe surroundings in Krasnodar Territory, Russia, and from Batumi District in Adzharia, Georgia. Its general distribution is described by Köckinger et al. (2010) as follow: mountainous parts of Atlantic Europe, Alps and SW Scandinavia; China. Its findings in the Caucasus obviously fill a gap in its distribution.

Specimens examined: RUSSIA: Krasnodar Territory, Sochi District, NW of Lazarevskoe (43 ${ }^{\circ} 57^{\prime} 12.4^{\prime \prime} \mathrm{N}, 39^{\circ} 18^{\prime} 43.2^{\prime \prime} \mathrm{E}$, ca. $80 \mathrm{~m}$ alt.), right bank of Kuapse Creek, Ignatov \& Ignatova \#12-41 (MHA, MW). GEORGIA: Adzharia: Batumi surroundings, Mtirola Mt., 20-21.VI.1961, A.L. Abramova \& I.I. Abramov s.n. (LE); Chakva River basin, Sachokhkas (?) Gorge, 15.IX.1946, V. Sochava s.n. (LE).

Oxystegus tenuirostris (Hook. \& Taylor) A.J.E. Sm., J. Bryol. 9: 393. 1977. - Weissia tenuirostris Hook. \& Taylor, Muscol. Brit. (ed. 2) 83. 1827. - Trichostomum tenuirostre (Hook. \& Taylor) Lindb., Öfvers. afFörh. Kong. Svenska Vetensk.-Akad. 21:225. 1864.

Description and illustrations: Bardunov (1969); SaviczLyubitskaya \& Smirnova (1970); Ignatov \& Ignatova (2003).

Oxystegus daldinianus and the slender form of Pseudosymblepharis bombayensis from the Caucasus were occasionally identified as $O$. tenuirostris; their distinction is discussed under these species. The latter species was also confused with Didymodon sinuosus, which has strongly fragile leaves with notched margins and often with fallenoff apical parts. However,at least in young upper leaves of D. sinuosus a coarse dentation of distal leaf margin is clear- 


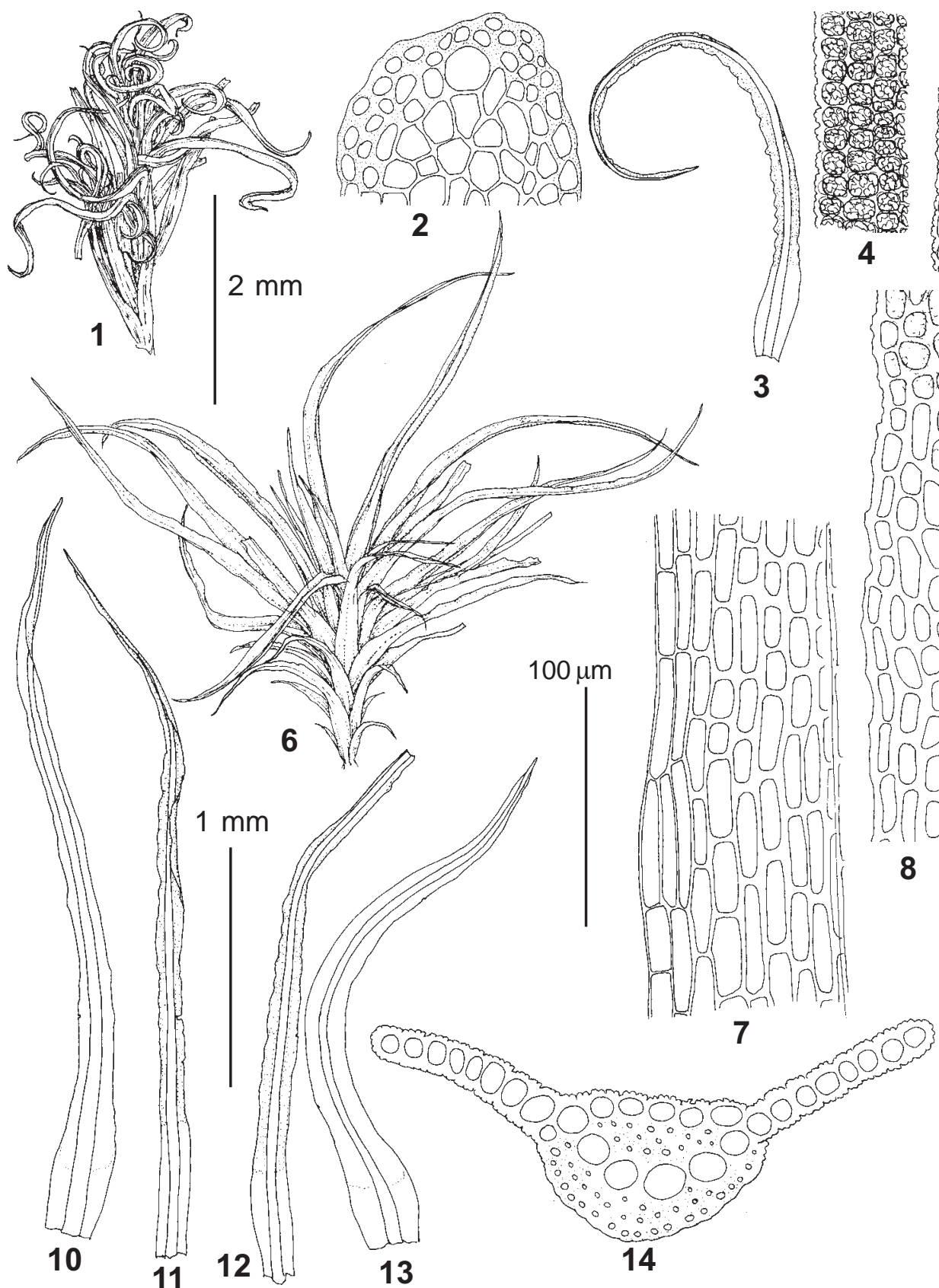

Fig. 3. Pseudosymblepharis bombayensis (Müll. Hal.) P. Sollman (1-12, 14-15 - from Russia, Dagestan, Gunib, Ignatov \& Ignatova \#09-313, MHA; 13 - from Dagestan, Tsudakhar, Abakarova \& Ignatov \#11297, MHA): 1 - habit, dry; 2 - stem transverse section; 3, 10-13 - leaves; 4-5 - upper laminal cells; 6 habit, wet; 7-8 - transition from basal to median laminal cells; 9 - distalmost cells of leaf lamina and surface cells of costa on abaxial side near leaf apex; 14 - leaf transverse section; 15 - basal laminal cells.
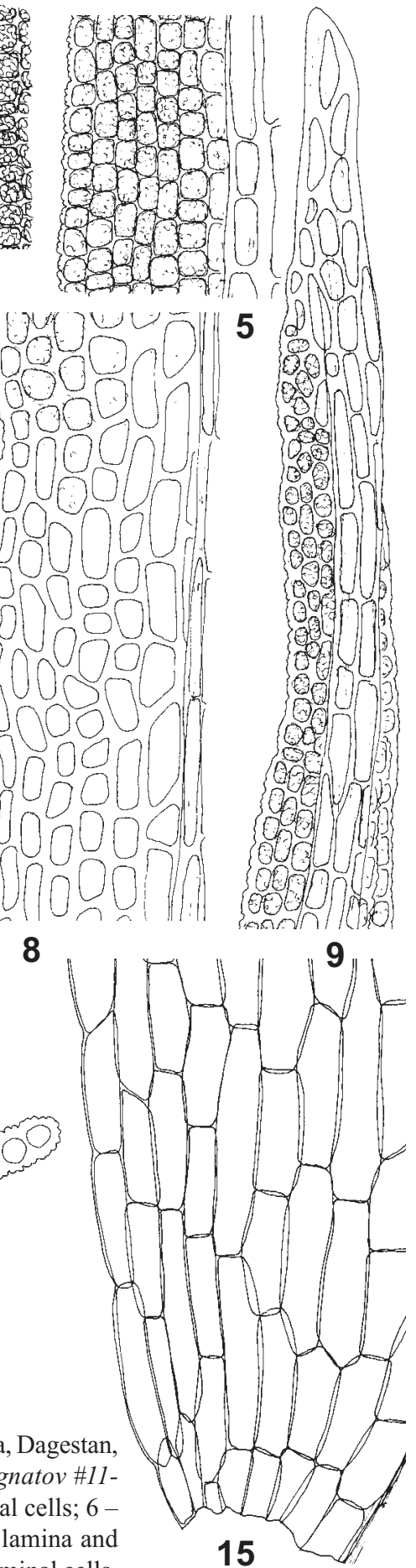

Scale bars: $2 \mathrm{~mm}$ for 1,$6 ; 1 \mathrm{~mm}$ for $3,10-13 ; 100 \mu \mathrm{m}$ for $2,4-5,7-9,14-15$.

ly seen; this character separates it from $O$. tenuirostris, which usually has notched distal leaf margins, or very rarely with few small denticulations. Furthermore, the basal leaf margin is narrowly recurved in D. sinuosus and plane in $O$. tenuirostris, and basal laminal cells are more sharply differentiated in the latter species.

Distribution and ecology. All records of $O$. tenuirostris from the Black Sea coastal area (Ignatov et al., 2002; Ignatova et al., 2005, etc.) were erroneous. The climate of this area is seemingly already too warm for the species. A revision of herbarium collections confirms its occurrence in mountainous regions of Karachaevo-Cherkessia, Kabardino-Balkaria, Adygeya, and Krasnodar Territory, where neutral or acidic bedrocks are rather common; few localities are known from Dagestan. It grows in shady and moderately wet habitats from forest to subalpine belt, occasionally in alpine meadows, on rocks, rock outcrops, fine soil, directly on rock surface and on soil layer. 
Zander (2007) outlines its area as extremely wide throughout the world, from Arctic to tropical areas on all continents. In Russia, O. tenuirostris was reported from almost all regions, mostly in mountains.

Selected specimens examined: RUSSIA: KarachaevoCherkessia: Teberda Nature Reserve, Amanauz River upstream of Dombai, $1650 \mathrm{~m}$ alt., Ignatov \& Ignatova \#05-3381 (MW); same place, Malaya Khatipara Creek upper course, $2800 \mathrm{~m}$ alt., Onipchenko \#175/96 (MW); Kabardino-Balkaria: CherekBezengijsky River valley, Dumala Creek, 1660 m alt., 31.VII.2004, Ignatov et al. s.n. (MW); Chegem River, Malye Chegemskie waterfalls, $890 \mathrm{~m}$ alt., Ignatov et al. \#05-1656 (MHA); Dagestan, Karak, 30.VI.1925, Bogdanovskaya-Gienef s.n. (LE); Krasnodar Territory: Caucasian Nature Reserve, Cherkessian Pass, 1600 m alt., 22.VIII.1999, Ignatov s.n. (MHA); Stavropol Territory, Kislovodsk, 1928, E. Schteinberg s.n. (LE). AZERBAIJAN: Zakatal'sky District, Shamilevka Mt. Range, 1800 m alt., 1.IX.1997, K. Korotkov s.n. (MW). GEORGIA: Bakuriani, 7.IX.1956, A.L. Abramova \& I.I. Abramov s.n. (LE).

Pseudosymblepharis bombayensis (Müll. Hal.) P. Sollman, Trop. Bryol. 12: 2. 1996. - Trichostomum bombayense Müll. Hal., Syn. Musc. Frond. 2: 628. 1851. - Chionoloma bombayense (Müll. Hal.) P. Sollman, Trop. Bryol. 20: 139. 2001.

Fig. 3.

NB: we provide a description of the Caucasian plants, which deviate considerably from typical forms of the species. This difference is discussed separately (see p.175).

Plants medium-sized, in loose tufts, yellowish green. Stems simple, ca. $5 \mathrm{~mm}$ long, evenly foliated, rounded in transverse section, hyalodermis absent, sclerodermis in 2-3 rows, medullar cells with moderately thickened walls, central strand absent or weak. Leaves strongly crisped to circinate when dry, patent when moist, \pm fragile, 4-6 mm long, 0.3-0.5 mm wide at base, linear lanceolate, limb concave to widely keeled, with parallel margins in middle part of leaf and gradually tapered in distal 1/4 of leaf, sheath longer than wide, slightly wider than limb or of the same width; costa strong, 80-100 $\mu \mathrm{m}$ wide at base, occupying(1/5-) 1/4 $1 / 3$ of limb width, gradually narrowing from base to apex, excurrent into short mucro, strongly prominent abaxially, in transverse section semicircular, with one row of guide cells, large dorsal and ventral stereid bands, adaxial epidermis differentiated, surface cells on adaxial side of costa subquadrate and papillose, surface cells on abaxial side of costa elongate rectangular, thick-walled, smooth throughout; margins plane, not to \pm strongly undulate, straight or notched; distal and median laminal cells subquadrate, 10$12(-14) \mu \mathrm{m}$, with moderately thickened walls, papillae moderately sized, bifid, dense, obscuring lumina; basal laminal cells rectangular, $40-90 \times 12-20 \mu \mathrm{m}$, hyaline, smooth, thinwalled, not porose, transition to papillose median cells gradual, cells of transitional zone thick-walled, yellowish, not or weakly porose; hyaline marginal cells often extending upwards along margin, forming not sharply delimited border. Dioicous. Perichaetial leaves with more wide sheathing base. Sporophytes not seen in specimens from the Caucasus (only plants with archegonia were observed).
Differentiation. Plants of Pseudosymblepharis bombayensis from the Caucasus were taken for long-leaved form of Oxystegus tenuirostris (Ignatov et al., 2010), especially due to their underdeveloped stature and leaves with hardly expanded sheath. The latter species is known as very variable. However, even in such long leaves of $O$. tenuirostris costa is weaker, it never occupies $1 / 3$ of leaf width, and leaves are less stiff. Furthermore, in Pseudosymblepharis bombayensis surface cells of costa on dorsal side are elongate and smooth throughout, while in $O$. tenuirostris they are shortly rectangular and subquadrate and often papillose in distal end of leaf. Densely papillose laminal cells are also helpful in separating of $P$. bombayensis from Oxystegus, which has smaller and more distant papillae, not obscuring cell lumina. An additional character is the hyaline border in basal part of leaf extending upwards along the margin.

Ecology. In Dagestan, P. bombayensis was collected in the areas with limestone bedrocks, at ca. $1730 \mathrm{~m}$ a.s.l., on rocky soil along a road in birch forest, and at $1160 \mathrm{~m}$, on open rocky place in stream valley. In Georgia, it grew at $2100 \mathrm{~m}$ a.s.l., near timberline, in cliff crevices [loamy shists and sandstone are most common in this territory].

Distribution. Pseudosymblepharis bombayensis was collected in three localities in the Caucasus, two of them, in Dagestan, being very close, ca. $20 \mathrm{~km}$ from each other, and the third one, in Eastern Georgia, at the distance ca. $80 \mathrm{~km}$.

The total range of $P$. bombayensis s.l. is overviewed by Sollman (2000). It is rather widespread in tropical and subtropical areas of Asia from China and Japan to India, Thailand, Papua New Guinea and Philippines and westward to Yemen and Socotra. The distance from its main area to the disjunct locality in the Caucasus is more than $3000 \mathrm{~km}$.

This is outstanding, but not the maximal case of disjunctive distribution between the Eastern Caucasus (Dagestan) and tropical areas. Ignatova et al (2010) described Lindbergia dagestanica Ignatova \& Ignatov, a separate species albeit very close to South and East African L. patentifolia Dixon. The closest locality of this relative in Ethiopia exceeds $4000 \mathrm{~km}$, and, similarly with Pseudosymblepharis, it is the first record in Europe (and moreover in Eurasia as a whole) of representative of the peculiar group of African and American Lindbergia (not formally recognized, but found to be distinct in molecular phylogeneric analysis).

Specimens examined: RUSSIA: Dagestan Republic: Gunib District, upper part of Gunib plateau, ca. $42^{\circ} 24^{\prime} \mathrm{N}, 46^{\circ} 55^{\prime} \mathrm{E}, 1730$ $\mathrm{m}$ alt., Ignatov \& Ignatova \#09-313 (MHA, MW); same place, ca.

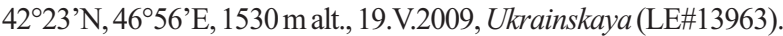
GEORGIA: Lagodekhi District, Lagodekhskoe Gorge, 17.IX.1952, A.L. Abramova \& I.I. Abramov (LE \#13936).

INDIA: Sikkim, North District, Bop, D.G. Long \#26379 (duplicate from E). SRI LANKA: Horton Plains, Diyagama, $C$. Ruinard \#17/51, 17/62-2; Hakgala Garden, C. Ruinard \#19/1222; Kandy District, Hunasgiriya Hill, C. Ruinard \#11/38 (duplicates received from Dr. Ph. Sollman). 


\section{ACKNOWLEDGEMENTS}

We cordially thank Dr. Philip Sollman for the great help with important literature and diplicates of specimens, Richard Zander for valuable comments and helpful discussion, and David Long for sending collections for comparison. We are also grateful to curators of LE for specimen loan. The work was partly supported by Biodiversity Program of RAS and RFBR 10-04-00678 and 12-04-32061.

\section{LITERATURE CITED}

[BARDUNOV, L.V.] БАРДУНОВ Л.В. 1969. Определитель листостебельных мхов Центральной Сибири. - [Handbook of mosses of the Central Siberia] Л., Наука [Leningrad, Nauka], 329 pp.

GARDINER, A., M. IGNATOV, S. HUTTUNEN \& A. TROITSKY 2005. On resurrection of the families Pseudoleskeaceae Schimp. and Pylaisiaceae Schimp. (Musci, Hypnales). - Taxon 54: 651-663.

GOLOBOFF, P.A. 1994. NONA: A Tree Searching Program. Program and documentation. Argentina, Tucumán, published by the author.

GUERRA, J., M.J. CANO \& R.M. ROS 2006. Flora Briofítica Ibérica. III. Pottiales: Pottiaceae. Encalyptales: Encalyptaceae. Sociedad Española de Briología, Murcia, Spain: 305 pp.

HALL, T.A. 1999. BioEdit: a user-friendly biological sequence alignment editor and analysis program for Windows 95/98/NT. Nucl. Acids. Symp. Ser. 41: 95-98.

HALLINGBÄCK, T., H. WEIBULL \& N. LÖNNEL 2008. Pottiaceae. - In: Hallingbäck, T., N. Lönnel, H. Weibull, L. Hedenäs, P. von Knorring, M. Korotynska, C. Reisborg \& M. Birgersson. Nationalnyckeln till Sveriges flora och fauna. Bladmossor: Kompaktmossor - kapmossor. Bryophyta: Anoectangium - Orthodontium. Uppsala, ArtDatabanken, SLU: 284-303.

IGNATOV, M.S., O.M. AFONINA \& E.A. IGNATOVA (eds.) 2006. Check-list of mosses of East Europe and North Asia. - Arctoa 15: $1-130$.

IGNATOV, M.S., V.E. FEDOSOV, E.A. IGNATOVA \& G.YA. DOROSHINA 2010. Moss flora of Gunib area in Dagestan, the eastern Caucasus. - Arctoa 19: 87-96

[IGNATOV, M.S. \& E.A. IGNATOVA] ИГНАТОВ M.C., Е.А. ИГНАТОВА 2003. Флора мхов средней части европейской России. Т. 1. - [Moss flora of the Middle European Russia. Vol. 1] M., KMK [Moscow, KMK]: $608 \mathrm{pp}$.
IGNATOV, M.S., E.A. IGNATOVA, T.V. AKATOVA \& N.A. KONSTANTINOVA 2002. Bryophytes of the Khosta' Taxus and Buxus Forest (Western Caucasus, Russia). - Arctoa 11: 205-214.

IGNATOVA, E.A., M.S. IGNATOV \& I.A. MILYUTINA 2010. A revision of the genus Lindbergia (Leskeaceae, Bryophyta) in Russia. - Arctoa 19: 97-116.

[IGNATOVA, E.A., M.S. IGNATOV, V.G. ONIPCHENKO, V.I. ZOLOTOV \& N.A. KONSTANTINOVA] ИГНАTOBA E.A., М.C. ИГНАТОВ, В.Г. ОНИПЧЕНКО, В.И. ЗОЛОТОВ, Н.А КОНСТАНТИНОВА 2007. Флора мохообразных Тебердинского заповедника. - [Bryophyte flora of the Teberda Reserve] Флора и фауна заповедников. Москва [Flora i fauna zapovednikov. Moscow] 112: $86 \mathrm{pp}$.

IGNATOVA, E.A., M.S. IGNATOV, A.P. SEREGIN, T.V. AKATOVA \& N.A. KONSTANTINOVA 2005. Bryophyte flora of the projected Utrish Nature Reserve (North-west Caucasus, Russia). - Arctoa 14: 39-48.

KHARZINOV, Z., N. PORTENIER, E. IGNATOVA, S. SHHAGAPSOEV \& M. IGNATOV 2004. Rare species and preliminary list of mosses of the Kabardino-Balkaria (Caucasus). - Arctoa 13: 33-40.

KÖCKINGER, H., O. WERNER \& R.M. ROS 2010. A new taxonomic approach to the genus Oxystegus (Pottiaceae, Bryophyta) in Europe based on molecular data. - Nova Hedwigia Beih. 138: 31-49.

NIXON, K.C. 1999. Winclada (BETA) ver. 0.9.9. available at http:/ /www.cladistics.com/about_winc.html.

[SAVICZ-LYUBITSKAYA, L.I. \& Z.N. SMIRNOVA] САВИЧЛЮБИЦКАЯ Л.И., З.Н. СМИРНОВА 1970. Определитель листостебельных мхов СССР. Верхоплодные мхи. - [Handbook of mosses of the USSR. The acrocarpous mosses] Л., Наука [Leningrad, Nauka], $822 \mathrm{pp}$.

SMITH, A.J.E. 2004. The moss flora of Britain and Ireland. 2 ed. - Cambridge, Cambridge University Press, 1012 pp.

SOLLMAN, P. 2000. A taxonomic revision of Pseudosymblepharis Broth. (Musci: Pottiaceae) in Asia. - Trop. Bryol. 18: 129-145.

WERNER, O., R.M. ROS \& M. GRUNDMAN 2005. Molecular phylogeny of Trichostomoideae (Pottiaceae, Bryophyta) based on nrITS sequence data. - Taxon 54: 351-358.

ZANDER, R.H.1993. Genera of the Pottiaceae: mosses of harsh environments. - Bull. Buffalo Soc. Nat. Sci. 32: 1-378.

ZANDER, R.H. 2007. Pottiaceae. - In: Fl. N. Amer. 27. Oxford University Press, New York: 476-481.

Appendix 1. GenBank accession numbers and voucher specimen data.

Oxystegus daldinianus: Austria 1 HM049778; Austria 2 HM049779; Austria 3 HM049780; Caucasus KC121302: Russia, Krasnodar Territory, Sochi District, Ignatov \& Ignatova \#12-41 (MHA); China HM049781; Ireland 1 HM049782; Ireland 2 HM049783; Ireland 3 HM049784; Norway HM049785; Oxystegus hibernicus (Mitt.) Hilp.: Ireland HM049786; Nepal HM049790; Oxystegus minor Köckinger, O. Werner \& Ros: Austria HM049792; Scotland AY796277; Oxystegus recurvifolius (Taylor) R.H. Zander: China HM049794; Scotland HM049795; Oxystegus tenuirostris: Austria 1 HM049797; Austria 2 HM049798; Austria 3 HM049799; Austria 4 HM049800; Austria 5 HM049801; Caucasus 1 KC121303: Russia, Karachaevo-Cherkessia, Teberda, Ignatov \& Ignatova \#05-3381 (MW); Caucasus 2 KC121304: Russia, Karachaevo-Cherkessia, Teberda, Egorov \#19/96 (MW); Caucasus 3 KC121305: Russia, Karachaevo-Cherkessia, Nizhnyaya Teberda, Onipchenko \#6/94 (MW); Caucasus 4 KC121306: Russia, Kabardino-Balkaria, Cherek-Bezengijsky, 31.VII.2004, Ignatov et al. s.n.(MHA); Commander Isl KC121307: Russia, Commander Islands, Bering Isl., Fedosov \#10-3-250 (MW); Germany 1 AY854428; Germany 2 AY854429; Kurils KC121308: Russia, Kuril Islands, Bakalin \#9-17-07 2007 (MHA); Primorsky KC121309: Russia, Primorsky Territory, Ignatov et al. \#06-2438 (MHA); Scotland HM049804; Spain 1 HM049802; Spain 2 HM049803; Ural KC121310: Russia, Perm Territory, Basegi, 8.VI.1994, Ignatov \#200 (MW); Yakutia KC121311: Russia, Yakutia, Mus-Khaya, Ignatov \& Ivanov \#11-3555 (MW); Oxystegus tenuirostris var. holtii (Braithw.) A.J.E. Sm.: England HM049807; France HM049805; Ireland 1 HM049806; Ireland 2 HM049808; Pleurochaete luteola (Besch.) Thér.: USA AY854395; Pleurochaete squarrosa (Brid.) Lindb.: Hungary AY854398; Italy DQ985181; Spain AY796265; Tunisia DQ985190; Pseudosymblepharis bombayensis: China AY796278; China 2 HM049776; Dagestan 1 KC121312: Russia, Dagestan, Gunib, Ignatov \& Ignatova \#09-313 (MHA); Dagestan 2 KC121313: Russia, Dagestan, Tsudakhar, Abakarova \& Ignatov \#11-297 (MHA); India HM049777; Pseudosymblepharis schimperiana (Paris) H.A. Crum: Costa Rica AY796276; Tortella bambergeri (Schimp.) Broth.: Spain HM049810; Tortella inclinata (R. Hedw.) Limpr.: Germany AY854420; Tortella tortuosa (Hedw.) Limpr.: Spain AY796266; Trichostomum brachydontium Bruch: Spain AY796255; Trichostomum crispulum Bruch: Spain 1 AY796249; Spain 2 AY796250; Trichostomum crispulum var. angustifolium Bruch \& Schimp.: Germany AY854426. 